\title{
CZEOWIEK TO KOMPUTER. O metaforach informatycznych w polszczyźnie codziennej
}

\section{A HUMAN IS A COMPUTER. On computer metaphors in everyday Polish}

\author{
Marcin Lewandowski \\ INSTYTUT JEZZYKOZNAWSTWA, UNIWERSYTET IM. ADAMA MICKIEWICZA \\ AL. NIEPODLEGŁOŚCI 4, 61-874 POZNAŃ \\ marcinleamu.edu.pl
}

\begin{abstract}
Abstrakt
Od kilkunastu lat obserwujemy zjawisko przenikania terminów informatycznych do slangu młodzieżowego jak również do polszczyzny ogólnej.Owe zapożyczenia funkcjonują $\mathrm{w}$ nowych, metaforycznych sensach. Celem artykułu jest przegląd i analiza metafor informatycznych, których znaczącą część można uznać za językowe poświadczenia proponowanej przez autora metafory konceptualnej CZŁOWIEK TO KOMPUTER. Podjęta zostanie również próba zrekonstruowania językowego obrazu człowieka, wyłaniającego się z tejmetafory.
\end{abstract}

\begin{abstract}
For more than ten years, computer terms have been borrowed into youth slang as well as standard Polish. These borrowings are used in new metaphorical senses. The paper aims to provide an overview and analysis of computer metaphors, many of which can be regarded as linguistic expressions underlying the conceptual metaphor A HUMAN IS A COMPUTER proposed by the author. An attempt will also be made to reconstruct the linguistic worldview generated by this metaphor.
\end{abstract}

\section{Wprowadzenie}

Stopniowe upowszechnianie się terminologii informatycznej na gruncie polszczyzny ogólnej pozostawało oczywiście w ścisłym związku z procesem intensywnej komputeryzacji społeczeństwa na początku lat 
dziewięćdziesiątych XX wieku. Kolejnym istotnym czynnikiem mającym wpływ na poszerzanie się zasobów leksykalnych języka specjalistycznego informatyki był rozwój Internetu w Polsce: w drugiej połowie ostatniej dekady ubiegłego wieku nastąpił gwałtowny wzrost liczby przedsiębiorstw $\mathrm{i}$ gospodarstw domowych z dostępem do globalnej sieci ${ }^{1}$.

Jednym z głównych sposobów wzbogacania polskiej leksyki komputerowej jest metaforyzacja. Metafory pełnią tym samym funkcję nominacyjną czy też katechretyczną (Patton 2002: 271; za Zawisławska 2010: 46-47), nazywając nowe pojęcia i wpływając zarazem na konkretny sposób ich konceptualizacji. Przykładami leksemów, które dzięki rozszerzeniom metaforycznym stały się integralną częścią słownictwa branży informatycznej, są takie podstawowe terminy, jak np.: pulpit, okno, ikona, plik, folder czy też mysz (komputerowa). Z kolei rozwojowi Internetu zawdzięczamy nowe znaczenia słów strona/witryna (internetowa), poczta (elektroniczna), portal, zakładka, przeglądarka i in. (w obu kategoriach dominują kalki semantyczne $\mathrm{z}$ języka angielskiego). Niewątpliwie $\mathrm{w}$ przypadku leksyki internetowej jedną z przyczyn dominującej roli procesu metaforyzacji jest skłonność do odwoływania się do pojęć znanych ze świata rzeczywistego w celu „oswojenia” rzeczywistości wirtualnej (DytmanStasieńko i Stasieńko 2008: 12). „Zjawiska w cyberprzestrzeni nazywa się używając środków służących do opisu świata realnie istniejącego, mimo że te dwie rzeczywistości nieraz znacznie różnią się od siebie" (Birecki 1997: 112).

Przyjmując optykę kognitywistyczną i odwołując się do teorii metafory pojęciowej Lakoffa i Johnsona (1988), której jedno z podstawowych założeń głosi, iż metafora wpływa na sposób postrzegania świata ${ }^{2}$, można pokusić się o wyróżnienie w szeroko rozumianym dyskursie informatycznym szeregu metafor konceptualnych. Jedną $\mathrm{z}$ nich będzie metafora KOMPUTER TO CZŁOWIEK (jej obecność dostrzegają m.in. Zawisławska 2010: 51 oraz Dancygier i Sweetser 2014: 30-31), której językowymi poświadczeniami są m.in. czasowniki odnoszące się do zmysłów, uczuć i czynności intelektualnych, np. myśleć, rozumieć, czytać, widzieć, lubić itp. (Komputer lubi się dtugo wczytywać, komputer myśli $i$ analizuje każdy ruch, np. podczas gry w szachy). Mamy tutaj do czynienia z przykładem metafory ontologicznej (w rozumieniu Lakoffa i Johnsona 1988: 48-57), która sprowadza się do tego, że przedmioty i zjawiska są postrzegane $\mathrm{w}$ kategoriach substancji, rzeczy i osób (w tym konkretnym przypadku ma miejsce proces personifikacji). Z kolei takie wyrażenia żeglować/surfować/buszować/wtóczyć się po Internecie czy też penetrować Internet (Birecki 1997: 92) można uznać za językowe

\footnotetext{
1 Niewątpliwie jednym $\mathrm{z}$ przełomowych wydarzeń, które przyczyniły się do upowszechnienia Internetu było uruchomienie przez Telekomunikację Polską usługi dostępu do Internetu dla abonentów tej firmy w lipcu 1996 r. Za: http://pclab.pl/art33917-6.html (data dostępu: 15 grudnia 2017).

${ }^{2}$ Jak twierdzą sami autorzy, „My [...] odkrywamy obecność metafory w życiu codziennym, nie tylko w języku, lecz też w myślach i czynach. System pojęć, którymi się zwykle posługujemy, by myśleć i działać, jest w swej istocie metaforyczny” (Lakoff i Johnson 1988: 25).
} 


\section{Marcin Lewandowski: CZŁOWIEK TO KOMPUTER. O metaforach informatycznych $w$ polszczyźnie codziennej}

poświadczenia metafory konceptualnej KORZYSTANIE Z ZASOBÓW WWW (INTERNETU) TO BEZKRESNA PODRÓŻ. Trafność tej metafory zostanie potwierdzona, a może nawet wzmocniona, jeśli $\mathrm{w}$ powyższych wyrażeniach nazwa Internet zastąpiona zostanie synonimicznym określeniem cyberprzestrzeń, która jest eksplorowana przez internautów, przywodzących - poprzez zastosowanie członu -nauta - na myśl astronautów czy też argonautów (na temat roli metafor Internetu por. Hendrykowski 2005 oraz Dytman-Stasieńko i Stasieńko 2008).

$\mathrm{Na}$ przestrzeni ostatnich kilkunastu lat obserwujemy zjawisko przenikania terminów informatycznych do polszczyzny codziennej (ogniwem pośredniczącym w tym procesie jest slang młodzieżowy, który przyswaja te terminy $\mathrm{w}$ pierwszej kolejności), w której stosowane są w znaczeniach metaforycznych. Można pokusić się w tym miejscu o konstatację, że niektóre słowa i wyrażenia dotyczące branży IT zostały już na tyle skutecznie przyswojone i zakorzenione $\mathrm{w}$ świadomości wielu użytkowników języka ogólnego, że pojawiają się one w metaforycznie przekształconych sensach $\mathrm{w}$ kontekstach związanych $\mathrm{z}$ zupełnie inną tematyką. Owa problematyka została dostrzeżona przez badaczy języka (por. Miodek 2006; 2007 i Maciołek 20133), a niektóre określenia zostały odnotowane w opracowaniach leksykograficznych (Zgółkowa 2004; Chaciński 2007).

Celem niniejszego artykułu jest przegląd metafor informatycznych występujących w ogólnej polszczyźnie, ze szczególnym uwzględnieniem językowych wykładników proponowanej przez autora metafory konceptualnej CZŁOWIEK TO KOMPUTER. Podjęta zostanie równiė̇ próba uchwycenia głównego znaczenia (ang. meaning focus, Kövecses 2010: 137-138) owej metafory, a więc wskazania tych cech domeny docelowej, które są w niej uwypuklone.

\section{Analiza materiału leksykalnego}

Przedstawiony w niniejszej sekcji materiał leksykalny wywodzi się w dużej mierze z Miejskiego słownika Slangu i mowy potocznej (pisownia oryginalna), dostępnego na stronie internetowej www.miejski.pl4. Słownik zawiera ok. 19 tys. definicji określeń funkcjonujących w mowie potocznej oraz slangu (dane z grudnia 2017 r.). Nie można jednak tego źródła uznać za profesjonalne opracowanie leksykograficzne, ponieważ hasła i definicje tworzone są przez internautów, których zdecydowana większość nie posiada odpowiednich kompetencji lingwistycznych do redagowania jakiegokolwiek

\footnotetext{
3 Napisany przez Marcina Maciołka artykuł różni się od niniejszego tekstu szerszym zakresem tematycznym (autor omawia zapożyczenia informatyczne nie tylko w potocznej polszczyźnie, ale również w tekstach literackich) oraz podejściem metodologicznym (w artykule z 2013 r. omówione są wyłącznie metafory językowe, podczas gdy w niniejszym tekście wykorzystana jest teoria metafory pojęciowej). Nie ma też pełnej zbieżności w kwestii zgromadzonego materiału leksykalnego: $\mathrm{w}$ niniejszym artykule pojawiają się określenia nie wymienione przez M. Maciołka, co należy tłumaczyć upływem czasu pomiędzy datami powstania obu tekstów i możliwym przyrostem zapożyczeń informatycznych w języku ogólnym.

4Pierwowzorem dla założycieli strony był zapewne tworzony od kilkunastu już lat anglojęzyczny słownik slangu Urban Dictionary (adres internetowy: www.urbandictionary.com).
} 
słownika. W tym internetowym słowniku znajduje się też niemała liczba okazjonalizmów - słów i frazeologizmów, którymi posługuje się bardzo niewielki krąg użytkowników polszczyzny (być może nieraz wyłącznie sami autorzy haseł). Dlatego zaprezentowany poniżej materiał leksykalny został poddany dość dokładnej weryfikacji przy użyciu wyszukiwarki Google: autor artykułu sprawdzał w ten sposób powszechność występowania terminów komputerowych $\mathrm{w}$ kontekstach niezwiązanych $\mathrm{z}$ informatyką. Dane empiryczne zostały uzupełnione określeniami znalezionymi $\mathrm{w}$ artykule opublikowanym na stronie internetowej magazynu Newsweek jak również kilkoma zasłyszanymi słowami i frazeologizmami, które także zostały poddane weryfikacji. Prezentowane określenia metaforyczne ilustrowane będą autentycznymi przykładami użycia, zaczerpniętymi z Internetu (częstokroć $\mathrm{z}$ forów dyskusyjnych, na których wypowiadają się młodzi ludzie), z zachowaniem oryginalnej pisowni, interpunkcji, stylistyki i składni.

Przegląd materiału leksykalnego rozpoczniemy od zapożyczeń informatycznych, które nie stanowią wykładników metafory konceptualnej CZŁOWIEK TO KOMPUTER (są to anglicyzmy, z których część została wymieniona we wspomnianym artykule Maciołka 2013). Należą do nich pejoratywne określenia człowieka: bot, pokemon i lamer. Bot używany jest w slangu młodzieżowym w odniesieniu do osób o niskim poziom inteligencji i wiedzy (Jak ty nie wiesz o co chodzi to niezty z Ciebie BOT5). Z kolei pokemon i lamer to określenia stosowane w odniesieniu do dyletantów (nie tylko w dziedzinie informatyki) - osób, które są nie tylko niekompetentne, ale próbują dodatkowo pouczać innych, łamiąc przy tym zasady netykiety (Co za lamer pisat ten artykuł doedukuj się TŁUKU zanim cos napiszesz). Pierwsze dwa leksemy wywodzą się z gier komputerowych. Bot (derywat angielskiego wyrazu robot) $\mathrm{w}$ swoim pierwotnym znaczeniu to program komputerowy, który wykonuje automatycznie szereg czynności w zastępstwie użytkownika (np. wyszukuje informacje w Internecie). Słowo to jest również używane w odniesieniu do wirtualnego przeciwnika w grach komputerowych. Pokemon (oryginalna pisownia: pokémon) to z kolei nazwa gatunku stworzeń - bohaterów filmów animowanych i gier komputerowych. Anglicyzm lamer wywodzi się z kolei ze slangu hakerów.

Innym anglicyzmem, który również coraz częściej stosowany jest $\mathrm{w}$ kontekstach nieinformatycznych, jest rzeczownik ban (pol. zakaz). Termin ten oznacza formalne uniemożliwienie dostępu (poprzez blokadę) konkretnemu użytkownikowi do korzystania $\mathrm{z}$ wybranych usług internetowych, przeważnie do zamieszczania wypowiedzi na forach internetowych czy też $w$ mediach społecznościowych. Wraz $z$ przeniesieniem do polszczyzny ogólnej, to prymarne znaczenie specjalistyczne zostało rozszerzone na wszelki rodzaj zakazu, czego przykładem jest następująca wypowiedź:

5 Wytłuszczenia we wszystkich cytatach pochodzą od autora niniejszego artykułu. 


\section{Marcin Lewandowski: CZŁOWIEK TO KOMPUTER. O metaforach informatycznych $w$ polszczyźnie codziennej}

Jeśli będzie część artystów, którzy będa ulegli, czy dosyć posłuszni wobec obecnych władz TVP,. to muszą się oni liczyć z tym, że obecne rządy nie trwają wiecznie. Jeśli PiS przegra za dwa lata, ono będą w czarnej dupie. Nie tylko będą bojkotowani w środowisku, ale będą też mieli „bana” na występy w telewizji. Przylgnie do nich łata - dla artysty nie ma niczego gorszego.

Czasownik trollować, derywowany od rzeczownika troll, pierwotnie stosowany był (i nadal jest) również w kontekście dyskusji na forach internetowych oraz $\mathrm{w}$ mediach społecznościowych. Trollowanie to inaczej działanie mające na celu prowokowanie i atakowanie innych internautów poprzez zamieszczanie obraźliwych, napastliwych i kontrowersyjnych treści. Czasownik trollować stosowany jest coraz częściej w podobnym znaczeniu nie tylko w kontekście komunikacji w świecie wirtualnym. Jako przykład niech posłuży następujący nagłówek z portalu natemat.pl: Jak "strollować" TVP za pomoca... koszulki. Genialna odpowiedź gościa TVP Info na bojkot WOŚP $P^{6}$. Z kolei czasownik tagować, którego pierwotne znaczenie to „umieszczać w tekście znaczniki (tagi)”, w slangu młodzieżowym posiada zmodyfikowany sens: słowo to oznacza czynność zamieszczania napisów bądź rysunków (Wytagowat ogromne, ociekające czernia logo Chanela na ścianie nad witryna sklepu Giorgio Armani). Czasownik zzipować (w znaczeniu informatycznym: „spakować pliki, tak aby zajmowały mniej miejsca na dysku") w sensie metaforycznym bywa stosowany jako synonim czasowników ścisnać się, ścieśnić się (Jak nie napchasz tam tyle co ja teraz (zzipowatem się już na zimę) a tylko taki zestaw jaki jest potrzebny na dana wodę $w$ danej porze roku, to zaczyna byc to bardzo wygodne). Dodajmy do tej listy jeszcze czasownik kampić, który stosowany jest w slangu miłośników gier internetowych w znaczeniu „zaczaić się, schować się w celu poczekania na ruch przeciwnika”. W rzeczywistości niewirtualnej leksem ten występuje w slangu młodzieżowym w podobnym sensie jako synonim czasowników ukryć się, schować (Skampiłem się na końcu klasy, zastonitem się ludźmi, i chciatem tam przesiedzieć obie lekcje, ale nie! Zauważyła, że jestem $w$ tej klasie, znalazła mnie na końcu sali, i przeniosła zaraz przed nia $w$ pierwszej ławce)7.

Przyjrzyjmy się teraz zapożyczeniom informatycznym, które stanowią językowe wykładniki metafory konceptualnej CZŁOWIEK TO KOMPUTER.

\footnotetext{
6 Wspomniany nagłówek dotyczy sytuacji, w której gość stacji telewizji informacyjnej TVP Info, dziennikarz Jacek Nizinkiewicz, podczas programu na żywo, emitowanego 15 stycznia 2017 r., spontanicznie zademonstrował element ubioru z emblematem Wielkiej Orkiestry Świątecznej Pomocy. W tym dniu media publiczne, w tym stacja TVP Info, zignorowały finał jednej z największych akcji charytatywnych organizowanych w Polsce, będącej do tej pory istotnym wydarzeniem medialnym. Więcej na ten temat: http://natemat.pl/199605,jak-strollowac-tvp-za-pomocakoszulki-genialna-odpowiedz-goscia-tvp-info-na-bojkot-wosp (data dostępu: 15 grudnia 2017).

7 Maciołek (2013: 171) wymienia ponadto kilka innych zapożyczeń z języki informatyki, które występują w slangu młodzieżowym (owe słowa i frazeologizmy zostały odnotowane w słowniku Zgółkowej 2004), m.in., haker - „zdrajca/uczeń posiadający dużą wiedzę”, komputer - „zdolny uczeń, wrzucić na dysk - „zapamiętać”, wpierdolićnortona - „zażyć LSD”.
} 
Wszystkie omawiane poniżej określenia metaforyczne w swoich prymarnych znaczeniach odnoszą się do funkcjonowania komputera.

Przegląd wyrażeń metaforycznych rozpocznijmy od czasowników zalogować się - „uzyskać dostęp do systemu komputerowego (również usług internetowych) poprzez wpisanie danych użytkownika (nazwy i hasła)” i wylogować się - „zakończyć pracę z systemem”. Oba czasowniki pojawiają się też czasem w kolokacjach z rzeczownikiem komputer (np. komputer zalogowat się do sieci). W języku potocznym zalogować się i wylogować się funkcjonują odpowiednio w znaczeniach „przyjść na świat, urodzić się"8 (Znajomemu zalogowato się dziecko) i „umrzeć” (Po takim wysitku nastapił zawat serca i Ole Bentzen definitywnie wylogowat się $z$ życia). W takim ujęciu całe życie ludzkie, od narodzin do śmierci, konceptualizowane jest $\mathrm{w}$ kategoriach funkcjonowania $\mathrm{w}$ systemie komputerowym czy też rzeczywistości wirtualnej.

Ciekawych danych językowych (kolejnych wykładników analizowanej metafory konceptualnej) dostarcza lektura artykułu opublikowanego na stronie internetowej tygodnika Newsweek. Okazuje się, że dwa terminy zaczerpnięte $\mathrm{z}$ języka informatyki (czy też szeroko rozumianej techniki) funkcjonują jako określenia metaforyczne w slangu seksoholików, czego poświadczeniem jest następujący fragment artykułu:

Niektórzy desperacko szukają pomocy w internecie, na stronach o zdrowiu, forach o masturbacji. Do kilkudziesięciu wysyłamy prośby o rozmowę, odsyłają odpowiedzi, że dziękują za zainteresowanie, ale nie, nie będą o tym opowiadać. Ci, którzy się w końcu godzą na rozmowę, starają się unikać słowa „seks”, tak źle im się kojarzy. Uciekają w slang. Zamiast powiedzieć, że nałogowo oglądali porno, chodzili na prostytutki, mieli stosunki pięć razy z rzędu, mówią: „Pięć razy się uruchamiałem”. Masturbacja to „uruchomienie samotnicze”. A gdy mówią: „skanowanie”, mają na myśli to, że jakaś kobieta wpadła im w oko, zapatrzyli się i poszło - już jej pożądali, wyobrażali sobie, że z nią robią różne rzeczy...9

Niewątpliwie mamy tu do czynienia z eufemizacją nazw czynności, które w przestrzeni publicznej podlegają tabuizacji. Przyglądanie się kobiecie $\mathrm{z}$ jednoczesnym snuciem fantazji erotycznych na jej temat

8 Ponadto zalogować się występuje również w znaczeniu „zgłosić swoją obecność” (Maciołek 2013: 171).

9Źródło: http://www.newsweek.pl/polska/spoleczenstwo/uzaleznieni-od-seksu-seksoholizmleczenie-w-polsce, artykuly,350330,1.html(data dostępu: 15 grudnia 2017). Jako dowód, że nie są to pojedyncze wystąpienia tych określeń niech posłużą dwa inne cytaty: „Zauważyłam, że skanuje każdą kobietę na ulicy, moją matkę, siostrę. Poźniej codziennie rano masturbował się jak prowadziłam starszą córkę do przedszkola" (wypowiedź z forum internetowego dotyczącego seksoholizmu), „Podglądałem kobiety $\mathrm{z}$ dachu wieżowca i uruchamiałem się seksualnie” (wypowiedź zamieszczona na stronie ośrodka terapii uzależnień). 


\section{Marcin Lewandowski: CZŁOWIEK TO KOMPUTER. O metaforach informatycznych $w$ polszczyźnie codziennej}

konceptualizowane jest jako skanowanie, a więc tworzenie zapisu pewnego obrazu. Z kolei onanizowanie się przyrównane jest do czynności uruchamiania się jakiegoś urządzenia, zazwyczaj komputera, lub programu komputerowego bądź gry komputerowej (warto zaznaczyć, że w polszczyźnie ogólnej czasownik uruchamiać się, podobnie zresztą jak skanować, nie występuje $\mathrm{w}$ połączeniach $\mathrm{z}$ rzeczownikami ożywionymi). Skoro uruchomić się to inaczej „zacząć funkcjonować”, można uznać, że w tym slangowym ujęciu funkcjonowanie człowieka sprowadza się do zaspokajania potrzeb seksualnych. Z kolei nazwy akcesoriów komputerowych, takich jak myszka czy joystick, pojawiają się we frazeologizmach klikać myszkę i bawić się joystickiem, które również stanowią eufemistyczne określenia masturbacji.

Warto jednak podkreślić, że omawiane w powyższym akapicie wyrażenia metaforyczne stosowane są przez relatywnie wąski krąg użytkowników polszczyzny. O wiele szerszy zasięg środowiskowy (nieograniczony wyłącznie do socjolektu młodzieżowego) ma niewątpliwie leksem reset jak również jego derywat czasownikowy resetować ${ }^{10}$. W swoim podstawowym, informatycznym znaczeniu reset to ponowne uruchomienie komputera (jego systemu operacyjnego) $\mathrm{z}$ reguły $\mathrm{w}$ związku $\mathrm{z}$ jego niewłaściwym funkcjonowaniem. W języku ogólnym leksem ten charakteryzuje się swoistą polisemicznością, występując $\mathrm{w}$ kilku metaforycznych sensach. Po pierwsze, reset rozumiany jest jako odnowa fizyczna, mentalna (Dwa tygodnie wcześniej nieoczekiwanie stracitam pracę. Stres, ciagte poszukiwanie nowej posady i wtedy mój przyjaciel wymyślit, że potrzebny jest mi reset), a nawet duchowo-religijna (Chrześcijańska dusza trafia do czyśćca, przecież nikt nie wie, jaka ma pokutę za dotychczasowe grzechy - może właśnie taki reset duszy, kasowanie starych błędów i praca na nowy rachunek $w$ nowym ciele?). Duchowo-religijny przekaz zawiera się również w haśle zachęcającym wiernych Kościoła katolickiego do przystępowania do sakramentu spowiedzi: Całodzienna Adoracja Najświętszego Sakramentu i Spowiedź Sw. Przyjdź $i$ zresetuj swoje sumienie. Inny sens leksemu reset odnajdziemy w następującej wypowiedzi: Kiedyś clubbing, dziś młodzi ludzie stawiaja na "reset". Nie chodzi jednak o odcięcie się od świata, z ksiażka albo filmem, tylko o weekendowy maraton alkoholowy z kacem, który pozwala nie myśleć o niczym innym. W tym przypadku chodzi oczywiście o doprowadzenie się do stanu upojenia alkoholem (reset może też odnosić się do odurzenia narkotycznego). Odmienne znaczenie metaforyczne pojawia się $\mathrm{w}$ języku polityki: reset $\mathrm{w}$ tym przypadku oznacza unormowanie czy też ułożenie na nowo stosunków politycznych (głównie międzynarodowych), czego poświadczeniem jest stwierdzenie: Chciatbym, żeby nastapit swoisty reset $w$ relacjach polsko-francuskich, które $w$ ostatnim czasie z różnych przyczyn bywały trudne - powiedział prezydent

${ }^{10} \mathrm{~W}$ metaforycznym znaczeniu stosowany jest również synonimiczny czasownik restartować się ( $W$ zeszłym roku, na zaproszenie włodarzy, odwiedzitem Ustkę i pomijając kwestie tego, że to jednak moja praca, to bawitem się świetnie, odpocząłem i zrestartowatem się). 
Andrzej Duda. Jakkolwiek omawiane sensy leksemu reset wykazują różnice, można powyższe rozważania podsumować konstatacją, że ich nadrzędną cechą wspólną jest potrzeba radykalnej zmiany (stanu mentalnego, świadomości czy też relacji politycznych).

Zwróćmy uwagę, że do języka potocznego przeniknęło kilka innych określeń (w większości anglicyzmów) dotyczących kondycji mentalnointelektualnej człowieka. Rzeczownik odczasownikowy loading, prymarnie oznaczający $\mathrm{w}$ języku angielskim ładowanie się strony internetowej bądź aplikacji, stosowany jest $\mathrm{w}$ znaczeniu stopniowego nabierania energii witalnej (Rozmwiatem nie raz z lekarzem $i$ mówit, że tak już jest $w$ tego typu substancjach, że zanim nie nasyci się nimi organizm, przyzwiczai się $w$ jakimś stopniu do nowej substancji, to jest właśnie taki loading kilkudniowy). Upgrade to z kolei ulepszenie sprzętu komputerowego bądź uaktualnienie aplikacji i gier komputerowych, co jest często powiązane $\mathrm{z}$ uzyskaniem dostępu do nowych funkcjonalności. Jako zapożyczenie ze słownictwa informatycznego leksem ten oznacza poprawę jakości życia ( $W$ 3mieście mam spokojnie tyle, że jakoś tam spoko żyję, rozważałem Wawę, by zrobić sobie upgrade życia). Określenia być/pracować/praca na stendbaju (ang. standby - tryb czuwania urządzenia) wywodzi się z języka korporacyjnego i odnosi się do przypadku świadczenia usług zawodowych niemal bez przerwy, gdy czas pracy jest praktycznie nielimitowany (Pracana,stendbaju” może wyczerpywać, a przecież na tyle dobrze sobie radzisz, że spokojnie mógtbyś być sam sobie sterem). W slangu informatycznym rzeczownik zawiecha to określenie sytuacji, w której komputer czy też program komputerowy się zawiesił, a więc przestał reagować na polecenia użytkownika. Słowo to przeniknęło do ogólnego slangu młodzieżowego, w którym oznacza stan chwilowego rozkojarzenia, niereagowania na bodźce zewnętrzne, skutkiem czego kontakt z taką osobą jest poważnie utrudniony (nie wiem jak wy [...] ale ja zlapalem zawieche $i$ siedzialem jeszcze do polowy napisow! sama koncowka jest mega zaj.bista!). W podobnym znaczeniu stosowany jest czasownik zawiesić się (Po nieco zbyt dużej ilości drinków zgubitem znajomka i zawiesiłem się, patrząc na autobusy). Człowieka można zaprogramować i sformatować, tak jak odpowiednio komputer i dysk lub inny nośnik danych. Czasownik programować funkcjonuje od dawna $\mathrm{w}$ szeroko rozumianym języku techniki w znaczeniu „nastawiać parametry, algorytm urządzenia sterującego pracą czegoś" (Dunaj 1999, t.2: 150). W polszczyźnie ogólnej słowo to oznacza „przygotować kogoś do określonego działania i zachowania”. Dobrym przykładem związków między obiema domenami kognitywnymi jest następująca wypowiedź dotycząca piłkarza Bartosza Kapustki: Kariera jak zaprogramowana $w$ komputerze, a on sam zaprogramowany na sukces. $\mathrm{Z}$ kolei formatować $\mathrm{w}$ znaczeniu prymarnym to „przygotować dysk lub inny stosowny nośnik do zapisu danych". Sens metaforyczny tego czasownika można wyjaśnić następująco: „wykształcić w kimś cechy i zachowania, które służą określonym celom”. Analizując konteksty, w których ten czasownik pojawia się w polszczyźnie ogólnej, można dojść do wniosku, że człowiek, który jest formatowany, jest 


\section{Marcin Lewandowski: CZŁOWIEK TO KOMPUTER. O metaforach informatycznych $w$ polszczyźnie codziennej}

podatny na kształtowanie pożądanych przez kogoś cech i zachowań (z tego względu trudno uznać czasowniki zaprogramować i sformatować jako leksemy synonimiczne). Dobrą ilustracją takiego właśnie sensu czasownika formatować jest następujący komentarz z forum dyskusyjnego:

$\mathrm{Z}$ tym formatowaniem to masz pan zupełną rację. Tylko, że u nas na Ojczyźnie też same przeformatowane ludzie chodzą. U nas na jednostce to jesteśmy, co prawda i na szczęście, od tego całego biznesu na zewnątrz odizolowani, ale jak posłuchać, co tam cywile z miasta mówią, to włos się pod hełmem jeży. Rodakom naszym to tu taki format na mózgu wypalili, że we wszystko już wierzą i wszystko łykają, globalne ocieplenie, wolne wybory, demokrację, holokaust, dopłatę zapasową, GMO, NWO i ZUS.

Na zakończenie omówmy jeszcze jeden przykład metafory językowej. Ludzki mózg bywa przyrównywany do procesora, czyli układu scalonego, który pobiera dane $\mathrm{z}$ pamięci operacyjnej, interpretuje je, a następnie wykonuje ciągi rozkazów. W ramach tej konceptualizacji na pierwszy plan wybija się zdolność mózgu do szybkiego analizowania i przetwarzania informacji. Leksem procesor w kontekstach metaforycznych stosowany jest $\mathrm{z}$ czasownikami uruchomić/ruszyć $\mathrm{w}$ trybie rozkazującym $\mathrm{w}$ znaczeniu „rusz mózgiem/zacznij myśleć”, np. Kolego ,uruchom swój procesor do myślenia. treśc zadania $w$ rzeczywistosci jest troche inna , brzmi: "na jakiej zasadzie działa sterownik tyrystorowy". Co to jest wedlug ciebie sterownik tyrystorowy ?. Silne dwukierunkowe relacje konceptualne pomiędzy mózgiem a procesorem (mózg bywa traktowany jako procesor, a procesor jako mózg) wynikają zapewne z faktu, że w początkowych stadiach rozwoju technologii informacyjnej komputer, którego jedną z centralnych części jest procesor, postrzegany był jako mózg czy też supermózg, który będzie w stanie konkurować z mózgiem ludzkim ${ }^{11}$.

\section{Podsumowanie i wnioski}

Omówiony powyżej materiał leksykalny składa się ze słów i frazeologizmów, które w metaforycznych znaczeniach przeniknęły do polszczyzny ogólnej stosunkowo niedawno, w ostatnich kilkunastu latach. Jakkolwiek użycie znacznej części leksemów ograniczone jest do konkretnych środowisk (głównie młodzieżowych), to warto podkreślić, że kilka z nich (np. reset, zawiesić się, formatować) funkcjonuje w szerszych kręgach społecznych, pojawiając się nie tylko w tekstach w stylu potocznym. Można uznać, że wskutek rewolucji technologicznej, która nastąpiła na przełomie tysiącleci, domena informatyczna została już na tyle „oswojona”, że sama stała się źródłem zapożyczeń do polszczyzny ogólnej. Szereg omawianych określeń to językowe wykładniki metafory pojęciowej CZŁOWIEK TO KOMPUTER.

${ }^{11}$ Więcej na ten temat por. Dytman-Stasieńko i Stasieńko (2008: 14-15) oraz Petersen O’Farrill (2015) 
Domena, która pierwotnie była wyłącznie domeną docelową (np. w metaforze KOMPUTER TO CZŁOWIEK), stała się tym samym domeną źródłową.

Powyższa obserwacja w żaden sposób jednak nie podważa jednego z głównych założeń teorii metafory pojęciowej, a mianowicie zasady jednokierunkowości metafor (nieodwracalności domen konceptualnych), która głosi, iż znaczenie przenoszone jest tylko w jednym kierunku: $\mathrm{z}$ domeny źródłowej do docelowej (Kövecses 2010: 7). Jak słusznie zauważają Dancygier i Sweetser (2014: 31), w sytuacjach, gdy dochodzi do zamiany ról domen, mamy do czynienia $\mathrm{z}$ odwzorowywaniem odmiennych ram semantycznych. W przypadku metafory CZŁOWIEK TO KOMPUTER przenoszona jest więc inna struktura znaczeniowa niż w przypadku metafory KOMPUTER TO CZŁOWIEK.

Pozostaje jeszcze odpowiedzieć na pytanie: jakie jest główne znaczenie metafory pojęciowej CZŁOWIEK TO KOMPUTER. Innymi słowy, jaki językowy obraz człowieka się z niej wyłania? Analizowana metafora konceptualizuje człowieka jako istotę funkcjonującą $\mathrm{w}$ pewnym systemie/rzeczywistości wirtualnej od początku do końca życia (używając określeń metaforycznych, od zalogowania do wylogowania). Szereg wykładników językowych dotyczy kondycji mentalno-intelektualnej człowieka, która jest postrzegana w kategoriach funkcjonowania komputera. Urządzenie to kojarzy się z takim cechami jak: automatyzm, skuteczność, wydajność i szybkość działania (nawet jeśli czasem dochodzi do zawieszenia systemu). Analizując konotacje kilku wykładników interesującej nas metafory, możemy mówić o efekcie hiperbolizacji, gdy porównamy te określenia $\mathrm{z}$ ich synonimami z domeny docelowej. Czynność skanowania przynosi trwalszy efekt niż zwykłe przyglądanie się, reset ma mocniejszy wydźwięk niż odnowa/zmiana, a formatowanie człowieka wydaje się skuteczniejsze niż kształtowanie w nim pożądanych cech i zachowań.

W związku z rosnącym znaczeniem technologii informacyjnej $\mathrm{w}$ różnych dziedzinach życia można przewidywać, że do języka ogólnego przenikać będą kolejne terminy informatyczne $\mathrm{w}$ zmodyfikowanych sensach. Być może rozszerzy się semantyka niektórych zapożyczeń wymienionych w niniejszym artykule. Wypada w tym kontekście zgodzić się z Wiertlewskim (2009: 60), który repertuar wykładników konkretnej metafory traktuje jako zbiór otwarty, w którym „można tworzyć kolejne [wyrażenia metaforyczne - ML] [...], wpisując się we wzorzec wyrażony przez metaforę konceptualną i nawiązując do domeny źródłowej poprzez dobudowywanie dalszych uszczegółowień”. 


\section{Marcin Lewandowski: CZŁOWIEK TO KOMPUTER. O metaforach informatycznych $w$ polszczyźnie codziennej}

\section{Bibliografia}

Birecki, T. 1997. Technika metafory $w$ konstruowaniu terminologii komputerowej (praca magisterska napisana pod kierunkiem prof. T. Zgółki). Poznań.

Chaciński, B. 2007. Totalny stownik najmłodszej polszczyzny. Kraków: Znak.

Dancygier, B., Sweetser, E. 2014. Figurative language. Cambridge: Cambridge University Press.

Dunaj, B. (Red.) 1999.Stownik współczesnego języka polskiego. Warszawa: Wilga Dytman-Stasieńko, A., Stasieńko, J. 2008. WWW - Sieć metafor, metafory Sieci i studia nad Siecią. w: A. Dytman-Stasieńko, J. Stasieńko (Red.) $W W W w$ sieci metafor: strona internetowa jako przedmiot badań naukowych. Wrocław: Wydawnictwo Naukowe Dolnośląskiej Szkoły Wyższej: 9-20.

Hendrykowski, M. 2005. Metafory Internetu. Poznań: Wydawnictwo Naukowe UAM.

Kövecses, Z. 2010. Metaphor: A Practical Introduction (2nd edition). Oxford: Oxford University Press.

Lakoff, G., Johnson, M. 1988. Metafory $w$ naszym życiu (tłum. T. P. Krzeszowski). Warszawa: Państwowy Instytut Wydawniczy.

Maciołek, M. 2013. Adaptacja terminów informatycznych w języku ogólnym i stylu artystycznym. w: W. Hajduk-Gawron, A. Madeja (Red.) Biblioteka „Postscriptum Polonistycznego”. Tom 3. Adaptacje I. Język - Literatura Sztuka. Katowice: Uniwersytet Śląski: 167-182.

Miodek, J. 2006. Ja się po akcji „resetuję”. Dziennik Zachodni (29.12. 2006).

Miodek, J. 2007. Rzeczywistość elektroniczna a język nasz powszedni. w: A. Mikołajczuk, R. Pawelec (Red.) Na językoznawczych ścieżkach. Prace ofiarowane profesorowi Jerzemu Podrackiemu. Warszawa: Semper: 103-106.

Patton, R. 2002. Systemic metaphors and integrative biology. Theoria et Historia Scientarium, vol. VI/1: 269-290.

Petersen O'Farrill, E. 2015. The use of metaphor and counterfactual thinking in "Computer machinery and intelligence" by Alan M. Turing. FRAGL 29.

Wiertlewski, S. 2009. Językowy obraz świata zapośredniczony w metaforach pojęciowych z obszaru socjolektu rowerowego. w: P. Nowak, P. Nowakowski (Red.) Język, Komunikacja, Informacja 4. 49-62.

Zawisławska, M. 2010. Metafora w języku naukowym - na przykładzie nauk przyrodniczych. Studia Semiotyczne 17: 47-58.

Zgółkowa, H. (Red.) 2004. Nowy stownik gwary uczniowskiej. Wrocław: Wydawnictwo Europa.

\section{Źródła internetowe}

http://pclab.pl/art33917-6.html (data dostępu: 15 grudnia 2017).

https://www.miejski.pl/ (data dostępu: 15 grudnia 2017).

http://natemat.pl/199605,jak-strollowac-tvp-za-pomoca-koszulki-genialnaodpowiedz-goscia-tvp-info-na-bojkot-wosp (data dostępu: 15 grudnia 2017).

http://www.newsweek.pl/polska/spoleczenstwo/uzaleznieni-od-seksuseksoholizm-leczenie-w-polsce, artykuly,350330,1.html (data dostępu: 15 grudnia 2017). 